\title{
The Red Queen: Margaret Drabble's (Auto)Biographical Pastiche
}

\begin{abstract}
Margaret Drabble's 2004 novel The Red Queen transgresses the generic borderlines between autobiography, biography and fiction. Drabble rewrites the published memoires of an eighteenth-century Korean Crown Princess with the help of two volumes of her biography, where she is known as Lady Hong or Hyegyong. Alongside the Princess's first-person narrative voice, Drabble has created her ghost voice addressing twenty-first century readers and comparing the time past with the time present. The novelist balances her avowed right to interpret and fictionalise with an undoubted respect for the original memoires. The article considers Drabble's mix of autobiography, biography and fictional narrative to examine the way she has contrived the The Red Queen as a playful but serious and moving autobiographical pastiche.
\end{abstract}

Key words

Margaret Drabble; The Red Queen; fictionalised (auto)biography

In 2004 Margaret Drabble published a novel which is very unlike any of her previous works of fiction, almost invariably situated in England in the second half of the twentieth century and portrayed realistically with little inclination towards fanciful experimenting. In contrast to that, The Red Queen not only ventures way beyond the temporal and geographical boundaries of contemporary Britain, but transgresses the generic borderlines between autobiography, biography and fiction. Inspired by memoires and biographies of the eighteenth-century Korean Crown Princess, also known as Lady Hong or Hyegyong, the novel employs a first person narrative voice, which is that of the Princess and also her ghost speaking to twenty-first-century readers, re-telling her life-story from two vantage points - the past and the present. Although Drabble voices some doubts 
about having appropriated autobiographical material in this manner, she defends her right as a novelist to do so. She balances her right to interpret and fictionalise with her deep admiration and respect for the disturbing original. This paper will attempt to navigate Drabble's heady brew of autobiography, biography, fictional narrative and metafictional devices with the aim of examining how she has constructed the intriguing autobiographical pastiche of The Red Queen.

Considering it has long been conceded that autobiography shares a great deal with fiction, because it cannot but, to a large extent, be a fictive rendering of the self, it is surprising that, in practice, autobiography and fiction remain separate not only as two strictly different genres, but even as two different fields of literary practice. The traditional distinction between autobiography and biography as non-fiction, and the myriad of their fictionalised forms as fiction, is still more or less strictly preserved, be it in specialised journals or on bookshop and library shelves.

The closeness of auto(biography) and fiction has come to stand out with the postmodern penchant for the mixing of genres as well as with all of the poststructuralist debate about authority, authorship and the authority of the narrative voice. In the area under consideration, Helen Cixous does not seem to see any difference between biography, autobiography and any other narrative. In her view, they all "tell one story in place of another" (qtd. in Anderson 2001: 1). This puts in plain and simple terms the complex poststructuralist undermining of any unified authoritative voice, whether fictional or non-fictional. Therefore, recent definitions of autobiography battle with questions of the identity of the author, of the narrator protagonist, of intention, of fact, truth and seriousness. The notion of the death of the author was followed by that of the death of autobiography in its wake, among others supported by Paul de Man's view of autobiography as a text in which the author "is a figure or a face called into being by the substitutive trope of prosopopoeia" (qtd. in Anderson 2001: 12). It has also been suggested that "women are less likely to be believed" as sincere authors of autobiography, because they are women (Anderson 2001: 3) and, therefore, less reliable narrators.

The long tradition of fictional (auto)biography, whether employing fictional or historical characters, has done little to erase the dividing line between fiction and non-fiction in this area of debate, very much in keeping with Mandel's commonsense statement that "every reader knows that autobiographies and novels are finally totally distinct" (qtd. in Anderson 2001: 6). By rewriting authentic autobiographical material and setting it together with wholly fictional chapters within a novel, Drabble undoubtedly confounds the distinction. The Red Queen rather resonates in accord with the concluding remarks of Anderson's recent overview of autobiography criticism, stressing "how impossible it is to decide once and for all about the status of autobiography as either truth or fiction" (2001: 132).

By closely interacting with authentic memoirs, The Red Queen occupies a unique place in the context of Drabble's novel writing. In other respects though, it bears similarities with all of Drabble's fiction, in the sense of relating women's lives against the social backdrop of the times. Her early novels of the 1960s were 
all concise, first-person narratives of young, intelligent, educated women battling with their social and family situation in changing Britain (e.g. The Garrick Year, 1964; The Millstone, 1965). During the 1970s and 80s, Drabble extended the temporal and sometimes spatial range of her novels, together with their broader canvasses of characters and omniscient narrators. But, women's lives again remained prominent in these realistically portrayed novel sequences, to use Steven Connor's term for novel cycles of social and historical consequence (1995: 136), which particularly Drabble's trilogy of the 1980s offers (The Radiant Way, 1987; A Natural Curiosity, 1989; The Gates of Ivory, 1991). Throughout the fifteen novels that preceded The Red Queen, Drabble traces a wide spectrum of intellectual and social discourses and examines their power play: the power of seductive (political) visions, of clever theories and their charismatic speakers, as well as the power that individuals can exert over others. The reverberations of the social context always decisively affect the novels' characters and their personal lives, and this is where the novels also visibly coincide with the story of The Red Queen. What can only be a mere coincidence, however interesting, is Drabble's return to first-person narrative in The Seven Sisters (2002), the novel immediately preceding The Red Queen, moreover a narrative in the form of diary entries, albeit of a comparatively short and not very dramatic series of events, in contrast to the memoirs of the Korean heroine of The Red Queen.

In The Red Queen the first half of the novel, or "Part One: The Ancient Times," closely follows its non-fictional models - The Memoirs of Lady Hyegyong (1995) and "Lady Hong," Memoirs of a Korean Queen (1985) - eighteenth-century autobiographies translated into modern English. As Drabble herself tells us in the Prologue, she was compelled by the uncanny power of the autobiographical story and its voice to carry on the message across times and cultures. She makes that leap from the eighteenth-century Korean royal court to the present European time with the aid of a metafictional ghost voice, with which the author of the memoirs comments on her own text from the vantage point of our time. With the ghost voice and its remarks and vision that have the benefit of hindsight, Drabble subverts both the fictionality and the historicity of her text. The reader is probably best advised to float on the wave of the narrator's story and discourse and not try to reason or puzzle out what is historical fact and what is fiction. Drabble herself seems to encourage and, at the same time, discourage either option. She is constantly reminding the reader that the incredible story of the memoir is historical, while the rational and well-informed ghost cannot, of course, solidify into fact.

The memoirs tell the life-story of a young girl of the Hong family who is offered as a bride to the Crown Prince, and who, after winning a formal competition at the Royal Palace, is married to him at the age of ten. The place and time is Korea at the beginning of the eighteenth century. Both the Crown Prince and Princess are children, and their marriage is only consummated when they reach the age of fifteen. The Crown Prince Sado is the King's only son, and their relationship is difficult. The King's exaggerated and disappointed expectations of his son turn into constant disparagement, which in turn results in the Crown Prince's 
violent and murderous paranoia. The King condemns his son to death in a ricechest, where, without a drop of his royal blood being spilt, it takes the ill-fated young man eight days and a heavy thunderstorm to die. His wife survives him by fifty years, as the mother of their son, the new Grand Heir and later King. During the seventy years of her life at the royal palace, she never left the palace grounds, as was required of her by the protocol and tradition, as well as by the dangers of palace intrigue and unpredictable royal whims and politics.

The tone of the memoir's voice is measured, but it conveys the drama, pain and fears of the lethal power games that included the ramified webs of royal wives, consorts, concubines and their offspring. Yet this is not an intimate confession, a self-seeking identity quest. It is a mere coincidence, to which no significance can be attached, that the original Korean memoir was written in the Princess's old age, roughly at the time when the English term "autobiography" was coined by Southey in 1809 . What seems more interesting to note is that the much older genre of diary and memoir tended to be more concerned with contexts and events than later autobiography and other modern forms of life writing, largely centred on the self. According to A. Robert Lee, among others, the focus on the self is particularly strong in the American tradition (1988: 7-14). In contrast to that, The Red Queen's first-person voice appears to be strangely selfless and even nameless, explaining that the names Lady Hong or Princess Hong given to her in the West are not her name and that she lost her title of the Crown Princess with the death of her husband. She says:

I have no name, and I have many names. I am a nameless woman. My true name is unknown to history. I am famous, but nameless. And I was never a queen in my lifetime, red or otherwise. I became a queen after my death. So much happens after death. (Drabble 2004: 25)

In her lifetime, after her husband's violent death, her name and her image were obliterated from records: "The silver throne is empty. I am not depicted. I am not there. I have no name, and I am not there. It was forbidden to depict me. No queen could ever sit for a male painter" (29-30), although the picture with the silver throne documented a grandiose ceremony lavished on her by her grandson the king to mark her $75^{\text {th }}$ birthday. The secret name "my little Red Queen" (49) was just an endearment bestowed on her by her husband Prince Sado when she was his child-bride aged ten and wearing her once coveted red silk skirt.

The memoirs of the Korean lady and their afterlife find their niche in contemporary criticism and the debate about the genre of autobiography, between the nineteenth-century, largely male model of it and recent uses of autobiography as "the text of the oppressed" (Anderson 2001: 104) or a text addressing the issues of difference in terms of class, race and sexuality. Unlike either of the two, the Princess's memoir is not struggling with how to construct herself as a subject, to use the now indispensable cliché, but rather with her experience of what was happening around her, the extreme events in the similarly extreme setting over- 
whelming all else. While it can hardly be disputed that in all writing, autobiography not excluding, the social and the political underlie any subjectivity, in The Red Queen the social and the political context is foregrounded and the narrator herself as a subject all but annihilated by the circumstances and the crushing events. This places the text close to Shoshana Felman's feminist view of "autobiography as a forum of testifying, to be distinguished from confession" (qtd. in Anderson 2001: 127), particularly in relation to trauma, which the Princess's life story abounds in. Deeply traumatic were the many losses she sustained early in her life: the loss of her family when she became the Crown Prince's wife, trapped in the rigours of palace life; the loss of her first-born baby boy; her husband's mental deterioration and cruel death. No less traumatic were the dangers of palace life amounting to a constant battle for survival. In this, the social testimony of Drabble's rewriting of the Princess's memoirs copies the pattern of all of her own fiction writing, in its strong social and cultural rootedness.

The original of the Crown Princess's memoirs is at least three-times removed from Drabble's rewriting. In "A Note on Sources" Drabble explains that she has read all three available translations into English of the several various existing copies of the original memoirs now lost (2004: 355). The process of copying and translation obviously places a number of interpretative voices between the Princess and Drabble. Apart from reviving the Princess's voice yet again in her novel, Drabble has given the Princess an extra voice, as her ghost roaming in our time. The posthumous voice is two-hundred-years older than the mature narrator of the original memoirs. Although the ghost voice may seem to undermine the reality and, thereby, even the credibility of the memoir, it does its best to negotiate the time and geographical distance and cultural difference between the original autobiographical story from the eighteenth century and the reader's time in the twenty-first century. Positioned in the early twenty-first century, the Princess's ghost can see some of the tragic events of her life more clearly, particularly in the light of modern medicine, the Crown Prince's untreated madness and what precipitated it, and the many "shocking things [...] that would now be forbidden by law in most nations on earth" (Drabble 2004: 14). On the other hand, both Drabble and her created ghost seem to claim insistently that "this posthumous revision" is done in the "belief that the universal exists" (8), and that it can bridge the gap between then and now. Drabble, thus, engages the Princess's autobiographical questioning voice in continuous comparison with our time, in order to respond to her plea: "collaborate with me in my undying search for the meaning of my sufferings and my survival" (6). Her resulting uncertainty of interpretation, too, resonates with our time: "I still cannot be certain. Death does not bring full light" (5). What is more, the ghost also reveals that the several original memoirs pursued particular agendas, further unsettling the veracity of the narrative: "During my lifetime, I wrote over a period of ten years four distinct memoirs, each time with a slightly different aim, each with its own revelations and evasions, each with its own agenda. I am trying to be truthful now, though I am not sure what agenda beyond truth a poor ghost might have. Perhaps even ghosts deceive 
themselves and others. However it may be, I find my ghostly memory is faulty and at time confused" (77). This fact as well as the Crown Princess's questions and uncertainty equivocate the view that a memoir has a tendency to fix, in contrast to a diary, which is more likely to show the Kristevan "'subject-in-process' [...] 'constantly called into question,"” as Anderson points out (2001: 94).

The ghost voice, which provides the link with our time, may also be understood in terms of what Maggie Maclure calls "self-talk" or "mundane autobiography" - what we say about ourselves in everyday affairs and what is "so routine and pervasive in our everyday lives that we would not ordinarily dignify it with the name of autobiography" (Maclure 1993: 373). However, this kind of transgression by the Princess's ghost voice is viewed critically by Preeta Samarasan, who feels that it exists "largely to facilitate Drabble's own polemical ends," but fails to afford us greater insight in the autobiography proper (2007: 5). Nevertheless, although rather unfashionably so, all three narrative voices of the novel, through whatever genre, claim to follow one aim: "The pursuit of truth is a noble aim. One lifetime is too short to discover truth. Therefore I persevere" (Drabble 2004: 78).

From the narratological point of view, the merging of narrative voices is nothing unusual in postmodern writing. Brian Richardson terms it "multiperson narration," while he recognises the difficulty it might cause the reader: "Still more compelling for the readers and potentially problematic for theory are texts in which the same character's thoughts and actions are narrated in different persons, or when entirely disparate narrators converge" (2006: 61). Fitting here might also be his suggested category of a "transparent narrator": "The 'transparent narrator' is a favourite technique of postmodern authors, who regularly use it to transgress the carefully maintained ontological boundaries observed by realist and modernist writers" (2006: 129). Drabble has obviously, although rather uncharacteristically, availed herself of this kind of technique in this novel. As the narrative flows, the Princess's voice of the memoirs and the commenting ghost voice are separate, entwined or merged into one, seamlessly, unpredictably and repeatedly. The permeability of the voices is aided by the fact that the ghost voice of the Red Queen, however fantastic, remains firmly anchored in realism and provides a link to contemporary reality.

The second half of the novel, entitled "Modern Times," abandons both firstperson voices of the autobiography and, through an omniscient narrator, tells the story of Dr. Barbara Halliwell's stay at an international conference in Seoul, South Korea. Although we can probably agree with Francis King that "the two halves of this diptych never really cohere" (King 2004: 2), Drabble has tried to tie them together with a number of parallels and explicit links. On the plane to Seoul, Babs Halliwell reads and is strongly affected by the memoirs of the Princess that had been sent to her by an anonymous donor. In Seoul she visits the appropriate tourist sites to walk in the Princess's footsteps. Two of the most important and defining features of her adult life parallel the Princess's: the loss of her baby boy and the madness of her husband. Babs becomes intensely interested in the Korean 
lady's biography, which she believes to be in need of retelling for today's readers. Finally, she finds and persuades the novelist Margaret Drabble to take up the challenge, and this is where the genres of biography and autobiography cross, eventually to merge.

From the reader's point of view though, the difference and distance between biography and autobiography does not appear to be very wide or significant. As Liz Stanley believes, "readers read autobiography [...] to find out about other people's lives; one way of reading autobiography, therefore, is to read it as biography" (qtd. in Anderson 2001: 89). From the writer's point of view, the two genres share the crucial problems of memory, perspective and choice of facts (cf. Penelope Lively's 1984 novel According to Mark or A. S. Byatt's 2000 novel The Biographer's Tale, both of which debate the biographer's dilemmas). Drabble had crossed the lines between the genres before, most conspicuously and recently in her novel The Peppered Moth (2000), a fictionalised biography of her mother, disapproved of by some (particularly her sister A. S. Byatt) for the negative picture it paints, by others precisely because she "disregarded the boundary between two literary genres" (d'Heurie 2001). Drabble's biographical writing is not all fictional or fictionalised. She is the author of two substantial biographies that of Arnold Bennett (1974) and Angus Wilson (1995) - and, therefore, is very much aware of and an adept at negotiating all the pitfalls of a biographer's work. Moreover, on the contemporary British literary scene, Drabble cannot be viewed as the lone player with fictionalised (auto)biography. Among notable examples of the genre there are several of Peter Ackroyd's novels (e.g. Chatterton, 1987; The House of Doctor Dee, 1993), Pat Barker's Regeneration trilogy (1991-95), Helen Dunmore's Zennor in Darkness (1993), or, even closer to Drabble's experiment, Colm Toibin's reworking of Henry James's notebooks in his 2004 novel The Master, described as "a fictional reconstruction of the internal life of Henry James, which drew liberally from James's notebooks" (Smee 2010).

The sometimes critical attitude to Drabble's (auto)biographical transgressions in The Red Queen, together with her Prologue to the novel, showing the need to explain and defend her solutions, are proof of the controversial nature of the subject. Drabble's kind of pastiche, both in the sense of rewriting the eighteenthcentury Korean memoirs and in the sense of a patchwork of styles, voices and metafictional intrusion, is a deliberate, rich postmodern mix of genre crossings. Playful experimenting, however, does not appear to be Drabble's primary purpose. She entrusts The Red Queen's narrative voices with axiological contemplation, stressing shared human values, no matter how different the cultures of the distant countries and times, and no matter through what voices or manner of writing they are conveyed. 


\section{References}

Anderson, Linda (2001) Autobiography. London and New York: Routledge.

Connor, Steven (1995) The English Novel in History 1950-1995. London: Routledge.

d'Heurie, Adma (2001) 'The Peppered Moth'. World Literature Today 75(3-4), 144-145. 28 June 2010. <http://lion.chadwyck.co.uk>.

Drabble, Margaret (2005 [2004]) The Red Queen. London: Viking; Penguin Books.

King, Francis (2004) 'Madness and Death in Korea'. The Spectator. 21 August 2004. 27 August 2010. <http://www.spectator.co.uk>.

Lee, A. Robert (ed.) (1988) 'Introduction'. In: First Person Singular: Studies in American Autobiography. London: Vision Press. 7-14.

Maclure, Maggie (1993) 'Mundane Autobiography: Some Thoughts on Self-Talk in Research Contexts'. British Journal of Sociology of Education 14(4). 24 June 2010. $<$ http://www.jstor.org >.

Samarasan, Preeta (2007) 'Putting Words in Other People's Mouths: On Empathy and Ventriloquism in Fiction'. Michigan Quarterly Review 46(1), 212-213. 28 June 2010. <http://lion.chadwyck.co.uk>.

Smee, Sebastian (2010) 'A Fragile Beauty'. The Spectator. 16 October 2010. 4 November 2010. $<$ www spectator.co.uk>.

Richardson, Brian (2006) Unnatural Voices: Extreme Narration in Modern and Contemporary Fiction. Columbus: Ohio State University Press.

Milada Franková is Professor in the Department of English and American Studies, Faculty of Arts, Masaryk University in Brno. She teaches British Literature and British Cultural Studies, and specialises in Medieval, Renaissance and Contemporary literature. Her current research interests involve the Contemporary British novel. She is the author of Human Relationships in the Novels of Iris Murdoch (1995), Britské spisovatelky na konci tisíciletí (British Women Writers at the End of the Millennium, 1999), Britské spisovatelky na přelomu tisíciletí (British Women Writers at the Turn of the Millennium, 2003) and co-editor of The Human Figure in (Post-)Modern Fantastic Literature and Film (2004).

Address: Prof. Milada Franková, Department of English and American Studies, Faculty of Arts, Masaryk University, Arne Nováka 1, 60200 Brno, Czech Republic. [email: frankova@phil.muni.cz] 